Diterbitkan Online Desember 2016 (http://journal.iain-manado.ac.id/index.php/jiep)

\title{
Merancang Pengembangan Madrasah Unggul
}

\author{
Agustini Buchari \\ Madrasah Aliyah Negeri Model Manado, Sulawesi Utara, Indonesia \\ Email:agustinibuchari@yahoo.co.id
}

\section{Erni Moh. Saleh}

Madrasah Aliyah Negeri Model Manado, Sulawesi Utara, Indonesia Email:ernysaleh28@gmail.com

ABSTRACT Preparation of human resources that are well-qualified and excellent is both an option and orientation for all types and levels of education. Madrasah as community-based educational institutions (community based education) have responsibility in preparing human resources and superior quality. To be able to continue actively preparing qualified human resources and excellent insight, innovative development of superior madrasah is required; which is developed to achieve excellence in output. To achieve this excellence, the input, the process of education, teachers and education personnels, management, education, and supporting facilities should be directed to support the achievement of this goal. Excellenct madrasas should be designed in accordance with the vision, mission and institutional objectives, and the need analysis of academic and institutional system. This should be done with an adequate understanding of the geographic and cultural context.

Keywords: Excellent madrasah, educational development, quality education

ABSTRAK Penyiapan sumber daya manusia yang berkualitas dan unggul merupakan pilihan sekaligus orientasi pendidikan pada semua jenis dan strata pendidikan. Madrasah sebagai lembaga pendidikan berbasis masyarak memiliki peran tanggung jawab yang sama dalam menyiapkan sumber daya manusia yang berkualitas dan unggul. Untuk dapat terus berperan aktif menyiapkan sumber daya manusia yang berkualitas dan memiliki wawasan keunggulan, diperlukan inovasi pengembangan madrasah unggul, yang dikembangkan untuk mencapai keunggulan dalam keluaran (output) pendidikanya. Untuk mencapai keunggulan tersebut, masukan (input), proses pendidikan, guru dan tenaga kependidikan, manajemen, layanan pendidikan, serta sarana penunjangnya harus diarahkan untuk menunjang tercapainya tujuan tersebut. Madrasah unggulan harus dirancang sesuai dengan visi-misi dan tujuan kelembagaan, analisis kebutuhan sistem akademik dan kelembagaan, dan memahami konteks geografis dan budaya.

Kata Kunci: Madrasah unggulan, pengembangan pendidikan, pendidikan berkualitas

\section{Pendahuluan}

Sebagai lembaga pendidikan yang sudah lama berkembang di Indonesia, pendidikan madrasah telah berhasil membina dan mengembangkan kehidupan beragama di Indonesia dan ikut berperan dalam menanamkan rasa kebangsaan ke dalam jiwa rakyat 
Indonesia. Madrasah juga telah berperan penting dalam mencerdaskan kehidupan bangsa. Oleh karena itu, peningkatan mutu, relevansi, dan daya saing madrasah di masa depan diharapkan dapat memberi dampak bagi perwujudan eksistensi sumber daya manusia Islam, sehingga dapat hidup bersama dalam keragaman sosial dan budaya. Upaya peningkatan mutu dan relevansi pendidikan madrasah pada gilirannya diharapkan dapat meningkatkan taraf hidup masyarakat serta daya saing bangsa, bagi warga masyarakat, khususnya masyarakat muslim.

Salah satu indikator mutu pendidikan madrasah adalah kualitas lulusannya. Sedangkan, aspek yang sangat dominan dalam peningkatan mutu penyelenggaraan pendidikan adalah kualifikasi guru, mutu manajemen, fasilitas (sarana dan prasarana), kurikulum, sistem yang diterapkan dan dana yang tersedia. Oleh karena itu, peningkatan kualitas SDM di lembaga-lembaga pendidikan Islam, merupakan suatu keharusan. Selain itu, penguatan tata kelola organisasi dan akuntabilitas pengelolaan madrasah juga dinilai signifikan dalam memengaruhi citra pendidikan madrasah.

Sudah barang tentu, sebagai lembaga pendidikan Islam, madrasah tidak hanya diarahkan kepada aktivitas penggalian ilmu pengetahuan semata, tetapi juga menjadi wahana pelatihan untuk mengaplikasikan ilmu pengetahuan pada tataran realitas. Selain itu, pendidikan di madrasah tidak hanya mengarah kepada keunggulan akademis (academic excellence), tetapi justru menegaskan orientasi pembentukan karakter (character building) yang berasaskan prinsip akhlakul karimah.

Madrasah sebagai lembaga pengembangan dakwah, dengan sendirinya menjadi salah satu tanda syiar agama sekaligus tampil sebagai komponen penting dari gerakan amar ma'ruf nahi munkar. Sebagai lembaga pendidikan masyarakat, madrasah berperan dalam pengembangan masyarakat sekitar (stakeholders) terutama terkait dengan masalah keagamaan maupun pemberdayaan sektor nonkeagamaan. Dengan demikian, madrasah merupakan pendidikan berbasis masyarakat (community based education). Peran aktif madrasah dalam pemberdayaan masyarakat sekitar dan sebaliknya peran aktif masyarakat dalam pengembangan madrasah akan menjadi amat penting, sehingga satu sama lain saling mendukung dalam meraih kemanfaatan dan kemaslahatan bersama (mutual support for the sake of mutual benefit).

Dalam konteks itulah, pengembangan madrasah tidak dapat ditangani secara parsial atau setengah-setengah, tetapi memerlukan pemikiran pengembangan yang utuh dan komprehensif serta langkah dan upaya yang visibel, fleksibel, dan kredibel, terutama ketika dihadapkan pada kebijakan pembangunan nasional bidang pendidikan yang mempunyai visi terwujudnya sistem pendidikan sebagai pranata sosial yang kuat dan berwibawa untuk memberdayakan semua warga negara Indonesia berkembang menjadi manusia yang berkualitas, sehingga mampu dan proaktif menjawab tantangan zaman yang selalu berubah (baca penjelasan UU No. 20/2003 tentang Sisdiknas). Ditambah lagi era globalisasi telah memberi dampak yang cukup luas dalam berbagai aspek kehidupan, termasuk tuntutan mutu dalam penyelengaraan pendidikan. Pada era ini setiap bidang menuntut SDM bermutu yang memiliki kemampuan tinggi, handal, dan kompetitif. Untuk memenuhi tuntutan ini, perbaikan dan pengembangan sistem penyelenggaraan pendidikan di madrasah secara berkesinambungan perlu dilakukan sejalan dengan dinamika perkembangan ilmu pengetahuan dan teknologi serta dinamika perubahan masyarakat itu sendiri. Penguatan keunggulan madrasah tersebut dengan cara membangun cita-cita dan kultur akademik yang kokoh hingga memunculkan output yang unggul dan baik sesuai harapan masyarakat. 


\section{Hakikat Madrasah Unggul}

Secara terminologis sekolah unggul adalah sekolah yang dikembangkan untuk mencapai keunggulan dalam keluaran (output) pendidikannya. Untuk mencapai keunggulan tersebut maka masukan (input), proses pendidikan, guru dan tenaga kependidikan, manajemen, layanan pendidikan, serta sarana penunjangnya harus diarahkan untuk menunjang tercapainya tujuan tersebut.

Di Indonesia, istilah sekolah unggul pertama kali digagas oleh Wardiman Djojonegoro (Mantan Menteri Pendidikan dan Kebudayaan) pada tahun 1994. Gagasan tersebut lahir dari adanya suatu keinginan kuat untuk menghadirkan sekolah sebagai lembaga pendidikan yang mempunyai visi yang jauh menjangkau ke depan dan berwawasan keunggulan. Bahkan Djojonegoro mengekspektasikan bahwa kehadiran sekolah unggul di setiap propinsi di Indonesia akan membuat terjadinya distribusi ilmu pengetahuan dan dengan demikian sasaran berikutnya ialah terjadinya akselerasi peningkatan sumber daya manusia (SDM). Oleh karena itu, kehadiran sekolah unggul bukan untuk diskriminasi, tetapi untuk menyiapkan SDM yang berkualitas dan memiliki wawasan keunggulan (Djojonegoro, 1998, p. 15).

Gagasan tentang sekolah unggul tersebut telah mendorong dikembangkannya konsep madrasah unggul. Madrasah unggulan adalah madrasah program unggulan yang lahir dari keinginan untuk memiliki madrasah yang mampu berprestasi di tingkat nasional dan dunia dalam penguasaan ilmu pengetahuan dan teknologi ditunjang oleh akhlakul karimah (Depag RI, 2004, p. 41). Dengan kata lain, pengembangan madrasah unggulan sejajar dengan pengembangan sekolah unggulan yang masing-masing dikembangkan untuk mencapai keunggulan dalam keluaran (output) pendidikannya. Untuk mencapai keunggulan tersebut, masukan (input), proses pendidikan, guru dan tenaga kependidikan, manajemen, layanan pendidikan, serta sarana penunjangnya harus diarahkan untuk menunjang tercapainya tujuan tersebut.

Dalam praktik di lapangan terdapat tiga tipe madrasah atau sekolah Islam unggulan (Moedjiarto, 2002, p. 34). Ketiga madrasah atau sekolah Islam unggulan tersebut, yaitu pertama, tipe madrasah atau sekolah Islam berbasis pada anak cerdas. Jenis tipe ini yaitu sekolah atau madrasah hanya menerima dan menyeleksi secara ketat calon siswa yang masuk dengan kriteria memiliki prestasi akademik yang tinggi. Meskipun proses belajar-mengajar di lingkungan madrasah atau sekolah Islam tersebut tidak terlalu istimewa bahkan biasa-biasa saja, namun karena input siswa yang unggul, maka memengaruhi outputnya tetap berkualitas.

Kedua, tipe madrasah atau sekolah Islam berbasis pada fasilitas. Sekolah Islam atau madrasah semacam ini cenderung menawarkan fasilitas yang serba lengkap dan memadai untuk menunjang kegiatan pembelajarannya. Tipe ini cenderung memasang tarif lebih tinggi ketimbang rata-rata sekolah atau madrasah pada umumnya.

Ketiga, tipe madrasah atau sekolah Islam berbasis pada iklim belajar. Tipe ini cenderung menekankan pada iklim belajar yang positif di lingkungan madrasah. Lembaga pendidikan dapat menerima dan mampu memproses siswa yang masuk (input) dengan prestasi rendah menjadi lulusan (output) yang bermutu tinggi. Tipe ketiga ini termasuk agak langka, karena harus bekerja ekstra keras untuk menghasilkan kualitas yang bagus.

Dari uraian di atas dapat didefinisikan bahwa madrasah unggulan adalah lembaga pendidikan Islam yang memiliki komponen unggul, yang tercermin pada sumber daya manusia (pendidik, tenaga kependidikan, dan siswa) sarana prasarana, serta fasilitas pendukung lainnya untuk menghasilkan lulusan yang mampu menguasai ilmu penge- 
tahuan dan teknologi secara terampil, memiliki kekokohan spiritual (iman dan/atau Islam), dan memiliki kepribadian akhlak mulia.

\section{Rasional dan Dasar Pemikiran Madrasah Unggul}

Undang-undang Dasar 1945 yang secara historis disebut sebagai Indonesian Declaration of Independence, dalam pembukaannya secara jelas mengungkapkan alasan didirikannya negara untuk (1) mempertahankan bangsa dan tanah air, (2) meningkatkan kesejahteraan rakyat, (3) mencerdaskan kehidupan bangsa, dan (4) ikut serta dalam mewujudkan perdamaian dunia yang abadi dan berkeadilan. Konsep pencerdasan kehidupan bangsa berlaku untuk semua komponen bangsa. Oleh karena itu, Undang-undang Dasar 1945 pada pasal 31 ayat (1) menyebutkan bahwa setiap warga negara berhak mendapatkan pendidikan, dan ayat (3) menegaskan bahwa pemerintah mengusahakan dan menyelenggarakan satu sistem pendidikan nasional yang meningkatkan keimanan dan ketaqwaan serta akhlak mulia. Sebagai lembaga pendidikan yang sudah lama berkembang di Indonesia, madrasah selain telah berhasil membina dan mengembangkan kehidupan beragama di Indonesia, juga ikut berperan dalam menanamkan rasa kebangsaan ke dalam jiwa rakyat Indonesia. Di samping itu, madrasah juga sangat berperan dalam mencerdaskan kehidupan bangsa.

Namun demikian, performa madrasah sampai saat ini masih sangat rendah. Beberapa permasalahan telah berhasil diidentifikasi menjadi penyebabnya, baik pada tingkat pengelolaan maupun kebijakan. Masalah kurikulum madrasah yang masih belum "fokus" dan proses pendidikan yang belum mendukung visi dan misi madrasah, merupakan contoh kasus di tingkat pengelolaan, sedangkan kebijakan pengembangan madrasah yang masih bersifat "tambal sulam" serta belum adanya blue print (cetak biru) pengembangan madrasah merupakan contoh kasus di bidang kebijakan.

Secara rinci dapat dikemukakan beberapa pokok permasalahan, baik pada tingkat pengelolaan maupun kebijakan sebagai berikut:

1. Pengembangan madrasah masih bersifat tambal sulam, hal ini misalnya terlihat dengan diadakannya program "keterampilan" yang ditempelkan pada program reguler, sebagai respon terhadap tingginya lulusan Madrasah Aliyah yang tidak bisa melanjutkan pada jenjang Pendidikan Tinggi. Demikian juga dengan program "keagamaan" sebagai respon terhadap lemahnya penguasaan ilmu keagamaan siswa, juga munculnya Madrasah Aliyah Unggulan (Insan Cendekia), yang merupakan langkah penyelamatan. Program-program tersebut meskipun banyak manfaat yang dapat diambil untuk proses pengembangan madrasah, tetapi langkah-langkah tersebut tampaknya tidak didasari oleh konsep yang terencana yang matang.

2. Kurikulum madrasah yang belum "fokus", hal ini terlihat misalnya, banyaknya materi yang diajarkan sementara waktu tidak memadai. Pada tingkat Aliyah, misalnya siswa yang ingin mendalami ilmu-ilmu keagamaan masih juga dibebani mata pelajaran lain yang tidak relevan dalam jumlah yang cukup banyak. Sebaliknya siswa yang mengambil jurusan IPA harus pula dibebani dengan banyaknya mata pelajaran lain yang tidak berhubungan secara langsung. Hal lainnya dalam kurikulum madrasah adalah masih adanya duplikasi materi yang diajarkan berulang-ulang pada mata pelajaran yang berbeda dan juga pada tingkat yang berbeda.

3. Akibat dari kurikulum yang belum "fokus" (bahan terlalu berat dan tumpang tindih), maka proses pendidikan yang terjadi di madrasah tidak sesuai dengan visi 
dan misi pendidikan madrasah. Program-program pengembangan yang sepotong-potong (parsial), dan tidak berangkat dari suatu desain yang terencana, juga diidentifikasi sebagai penyebab tidak bertemunya visi-misi madrasah dengan pendidikan yang diberikan.

4. Ketidakadaan cetak biru (blue print) pengembangan madrasah, ini barangkali permasalah yang paling mendasar, sehingga pengembangan madrasah menjadi tidak memiliki arah (Depag RI, 2004, pp. 1-5).

Dari uraian di atas, dapat ditarik benang merah bahwa munculnya sekolah unggulan berangkat dari keinginan untuk menciptakan madrasah yang menjadi central for exellence untuk mempersiapkan SDM yang siap pakai untuk masa depan. Selama ini data menunjukkan bahwa mutu pendidikan nasional belum merata. Adanya sekolah unggulan dapat membekali mereka dengan pengalaman belajar yang berkualitas, dengan sendirinya mereka mempunyai peluang yang lebih besar untuk memasuki jenjang pendidikan yang lebih tinggi sesuai dengan pilihannya.

Pada sisi lain, harus diakui bahwa masyarakat Indonesia tidak sedikit yang lebih memercayai lembaga pendidikan madrasah daripada sekolah umum. Lembaga pendidikan Islam ini diminati oleh masyarakat yang menghendaki para putra-putrinya memperoleh pendidikan agama yang cukup sekaligus pendidikan umum yang memadai. Namun, ada empat masalah utama yang sedang dihadapi oleh madrasah pada umumnya, yaitu: masalah identitas diri madrasah, masalah jenis pendidikan yang dipilih sesuai titik tekan keagamaan, masalah kemunduran kualitas ajaran Islam yang berimplikasi pada kedangkalan pemahaman Islam dan masalah sumber daya internal yang ada dan pemanfaatannya bagi pembangunan madrasah sendiri di masa depan (Muhaimin, 2005, p. 186). Untuk itu, pemikiran pengembangan madrasah unggul dinilai relevan dengan upaya pemberdayaan sumber daya manusia di Indonesia.

Dalam hal lain, juga perlu dikemukakan bahwa gagasan pengembangan madrasah dapat dilihat dari dua dasar utama, yaitu dasar religius dan dasar yuridis. Berikut adalah penjabaran kedua dasar yang dimaksud.

\section{Dasar Religius}

Islam memerintahkan belajar pada ayat pertama yang diturunkan pada Rasulullah Saw. Oleh karena itulah belajar merupakan kewajiban utama dan sarana terbaik mencerdaskan umat (Muhaimin, 2005, p. 186). Perintah belajar tersebut tidak terbatas pada urusan duniawi saja, tetapi juga dalam urusan ukhrawi. Firman Allah Swt., dalam Al Qur'an surat At-Taubah ayat 122, yang terjemahannya:

"Tidak sepatutnya bagi orang-orang yang mukmin itu pergi semuanya (ke medan perang). Mengapa tidak pergi dari tiap-tiap golongan di antara mereka beberapa orang untuk memperdalam pengetahuan mereka tentang agama dan untuk memberi peringatan kepada kaumnya apabila mereka telah kembali kepadanya, supaya mereka itu dapat menjaga dirinya." (Q.S At-Taubah: 122)

Lafadz "liyatafaqqahuu fidiin" dalam surat At-Taubah ayat 122 itu memberi isyarat tentang kewajiban memperdalam ilmu agama (Nata, 2002, p. 159). Artinya, seorang muslim perlu mendalami ilmu agama dan mengajarkan kepada orang lain berdasarkan kadar yang diperkirakan dapat memberikan kemaslahatan bagi mereka, sehingga memberikan pengetahuan hukum-hukum agama yang pada umumnya harus diketahui oleh orang-orang beriman. Hal ini disebabkan banyaknya orang yang pintar dalam urusan duniawi namun mereka lalai dalam urusan akherat. Firman Allah Swt., dalam Alquran surat Ar Rum ayat 7, yang terjemahannya: 
"Mereka hanya mengetahui yang lahir (saja) dari kehidupan dunia; sedang mereka tentang (kehidupan) akhirat adalah lalai." (Q.S. Ar Rum: 7).

Jadi belajar agama merupakan suatu hal yang sangat penting bagi seorang muslim sebagai benteng yang dapat menjaga diri dan tetap dalam koridor yang disyariatkan. Begitu pentingnya belajar agama sehingga Allah Swt., memberikan kedudukan tinggi pada orang yang memusatkan perhatian mendalami ilmu agama sebagaimana derajatnya orang-orang berjihad dengan harta dan dirinya dalam rangka meninggikan kalimah Allah Swt. Salah satu cara yang bisa dilakukan dengan belajar di sebuah lembaga yang khusus mengajarkan ilmu-ilmu agama yaitu madrasah.

\section{Dasar Yuridis}

Penyelenggaraan Madrasah secara yuridis diatur dalam tata perundangan kita. Sila pertama yang menyebutkan Ketuhanan Yang Maha Esa memiliki makna bahwa agama dijadikan sebagai pembimbing sekaligus keseimbangan hidup bangsa Indonesia. Ini berarti bahwa lembaga keagamaan seperti madrasah diakui sebagai tempat pembinaan mental spiritual bangsa indonesia. Secara konstitusional pasal 29 ayat 2 negara menjamin kebebasan rakyatnya dalam melaksanakan ajaran agamanya. Termasuk kebebasan belajar di madrasah. Pasal 31 ayat 3 menyebutkan bahwa pemerintah mengusahakan satu sistem pendidikan nasional yang meningkatkan keimanan dan ketakwaan serta akhlak mulia dalam mencerdaskan kehidupan bangsa, salah satunya adalah penyelenggaraan Madrasah. Secara operasional ketentuan Madrasah terakhir diatur dalam keputusan menteri agama No. 1 tahun 2001 setelah lahirnya Direktorat Pendidikan Keagamaan dan Pondok Pesantren khususnya melayani pondok pesantren dan madrasah. Keberadaan madrasah sebagai bagian dari sistem pendidikan nasional diperkuat dengan lahirnya Undang-undang No. 20 tahun 2003 terutama pasal 30 ayat 1 hingga 4 yang menyatakan bahwa pendidikan keagamaan dapat diselenggarakan oleh pemerintah dan atau kelompok masyarakat dari pemeluk agama sesuai dengan peraturan perundangan.

Berdasarkan pada Undang-undang No. 20 tahun 2003 itu, maka dipahami bahwa (1) pendidikan keagamaan dapat diselenggarakan oleh pemerintah (pendidikan keagamaan negeri) dan dapat diselenggarakan oleh masyarakat (pendidikan keagamaan swasta); (2) Pendidikan keagamaan berfungsi mempersiapkan peserta didik menjadi anggota masyarakat yang memahami dan mengamalkan nilai-nilai agamanya dan atau menjadi ahli ilmu agama; (3) Pendidikan keagamaan dapat diselenggarakan pada jalur formal, nonformal dan informal. Ketentuan ini memberikan ruang yang sangat luas pada lembaga pendidikan keagamaan untuk menyelenggarakan pendidikan pada jalur formal persekolahan, nonformal seperti kursus, pelatihan, kelompok belajar keagamaan (majelis taklim), atau jalur informal seperti pendidikan dalam keluarga; dan (4) Pendidikan keagamaan berbentuk pendidikan madrasah, pesantren, dan bentuk lain yang sejenis.

Berdasarkan alasan-alasan tersebut, maka perlu dikembangkan madrasah-madrasah unggul dengan manajemen yang profesional dalam rangka meningkatkan mutu atau kualitas pendidikan, khususnya pendidikan yang berbasis agama.

\section{Karakteristik Madrasah Unggul}

Secara teoretis, karakteristik madrasah unggul bisa diklasifikasi ke dalam beberapa kriteria, antara lain: keunggulan proses pembelajaran, keunggulan sarana-prasarana atau fasilitas belajar, keunggulan lingkungan pendidikan, keunggulan kognitif, keunggulan 
ekstrakuriler, keunggulan mulok, keunggulan life skill, keunggulan administrasi, dan lain-lain. Tentu yang dikehendaki adalah keunggulan multifacet.

Kemendikbud umpamanya, menetapkan kriteria sekolah unggul sebagai berikut: (1) input siswa melalui seleksi yang ketat berdasarkan kriteria dan standar; (2) sarana prasarana belajar yang memadai, baik intra maupun ekstra; (3) lingkungan sekolah yang kondusif; (4) guru dan tenaga kependidikan yang memiliki kualifikasi sesuai dengan persyaratan dan ketetapan Undang-undang Guru dan Dosen tahun 2005; (5) kurikulum yang diperkaya, yang mampu mengembangkan dan memfasilitasi potensi, bakat, kreasi siswa; (6) Rentang waktu belajar di sekolah lebih panjang; (7) proses belajar mengajar yang berkualitas; (8) perlakuan tambahan di luar kurikulum nasional; dan (9) menjadi pusat keunggulan bagi sekolah-sekolah di sekitarnya (Subhan, 2006, p. 19).

Berbeda dengan madrasah model yang secara umum persyaratan yang dikriteriakan ialah (1) memiliki manajemen madrasah yang baik; (2) SDM yang berkualitas; (3) kelengkapan sarana dan prasarana pendidikan; (4) bantuan pendidikan yang memadai; dan (5) keunggulan kualitas lulusan (Fachruddin, 1998, p. 80).

Harris and Bennett (dalam Jalal, 2012) mengemukakan bahwa karakrektistik sekolah unggul, yaitu: (1) Kepemimpinan yang profesional (Profesional Leadership); (2) Visi dan tujuan bersama (Shared Vision and Goals); (3) Lingkungan belajar (a Learning Environment); (4) Konsentrasi pada belajar-mengajar (Concentration on Learning and Teaching); (5) Harapan yang tinggi (High Expectation); (6) Penguatan/pengayaan/ pemantapan yang positif (Positive Reinforcement); (7) Pemantauan kemajuan (Monitoring Progress); (8) Hak dan tanggung jawab peserta didik (Pupil Rights and Responsibility); (9) Pengajaran yang penuh makna (Purposeful Teaching); (10) Organisasi pembelajar (a Learning Organization); dan (11) Kemitraan keluargasekolah (Home-School Partnership).

Dari semua kriteria tentang madrasah atau sekolah unggul atau madrasah model pasti dirujuk pada Peraturan Pemerintah No. 19/2005 tentang Standar Nasional Pendidikan (SNP) yang menjadi kriteria minimal sistem pendidikan di seluruh Indonesia. Standarisasi pendidikan ini berfungsi sebagai dasar dalam perencanaan, pelaksanaan, dan pengawasan pendidikan dalam rangka mewujudkan pendidikan nasional yang bermutu. Artinya, jika madrasah telah memenuhi semua atau sebagian besar kriteria SNP, maka madrasah tersebut disebut sebagai Madrasah Standar Nasional (MSN) atau Madrasah Kategori Mandiri (MKM). Dalam posisi ini madrasah berada pada level Unggulan atau Model, selanjutnya meningkat statusnya menjadi Madrasah Standar Internasional (MSI), akan berada pada level Model yang menjadi idealisasi sebuah madrasah.

Dalam konteks madrasah, Zayadi (2005, p. 57) mengemukakan beberapa unsur karakteristik madrasah unggul ialah: pertama, aspek administrasi atau manajemen, yaitu (1) maksimal 6 kelas untuk tiap tingkatan, (2) tiap kelas terdiri atas 30 siswa, (3) rasio guru kelas adalah 1:25, (4) mendokumentasi perkembangan tiap siswa, dan (5) transparan dan akuntabel. Kedua, aspek ketenagaan, yaitu (1) kepala madrasah yaitu (a) minimal S2 untuk MA, S1 untuk Madrasah Tsanawiyah (MTs) dan Madrasah Ibtidaiyah (MI), (b) pengalaman minimal 5 tahun menjadi kepala madrasah, (c) mampu berbahasa Arab atau berbahasa Inggris, (d) lulus tes (fit and proper test), (e) sistem kontrak satu tahunan, dan (f) siap tinggal di kompleks madrasah, (2) guru, yaitu (a) minimal S1, (b) spesialisasi sesuai mata pelajaran, (c) pengalaman mengajar minimal 5 tahun, (d) mampu berbahasa Arab atau bahasa Inggris, (e) lulus test (fit and proper test), dan (f) sistem kontrak 1 tahun, (3) tenaga kependidikan, yaitu (a) minimal S1, (b) spesialisasi sesuai dengan bidang tugas, dan (c) pengalaman mengelola minimal 3 tahun. Ketiga, 
aspek kesiswaan terdiri dari (1) input, yaitu (a) sepuluh besar MTs (untuk MA), (b) sepuluh besar MI (untuk MTs), dan (c) lulus tes akademik (bahasa Arab dan Inggris) dan (2) output, yaitu (a) menguasai berbagai disiplin ilmu, (b) mampu berbahasa Arab maupun bahasa Inggris, (c) terampil menulis dan berbicara (Indonesia) dengan baik, dan (d) siap bersaing untuk memasuki jenjang lebih tinggi yakni universitas atau institut bermutu di dalam negeri. Keempat, aspek kultur belajar, yaitu (1) full day school, (2) student centered learning, (3) kurikulum dikembangkan dengan melibatkan seluruh elemen madrasah termasuk siswa, (4) bahasa pengantar Arab dan Inggris, (5) sistem droup out, dan (6) pendekatan belajar dengan fleksibelitas tinggi dengan mengikuti perkembangan metode-metode pembelajaran terbaru. Dan, kelima, aspek sarana dan prasarana, yaitu (1) perpustakaan yang memadai, (2) laboratorium (IPA, Bahasa dan Matematika), (3) laboratorium alam yang memadai, (4) mushalla, dan (5) lapangan dan fasilitas olahraga lainnya yang memadai.

Terkait dengan madrasah unggul dan model, Mastuhu (1994, p. 58) menglasifikasi kriteria madrasah unggul ke dalam dua hal, yaitu: (1) sumber daya manusia (SDM) dan (2) perangkat pendidikan. Sumber daya manusia terdiri atas pimpinan madrasah, guru, siswa, dan tenaga kependidikan. Perangkat keras (hardware) berupa bangunan madrasah, masjid, lapangan olahraga, dan fasilitas pendidikan lainnya. Perangkat lunak (software) berupa visi, misi, tujuan, kurikulum, metode pembelajaran sistem penilaian, dan lain-lain (Mastuhu, 1994, p. 58). Dengan demikian, kriteria, karakteristik dan standar madrasah dapat dikelompokkan ke dalam dua substansi utama, yaitu sistem kelembagaan dan sistem pembelajaran.

Dalam konteks pendidikan di Indonesia, pemerintah telah memberikan ramburambu, bagaimana menciptakan sekolah/madrasah yang memiliki kualitas baik. Salah satunya adalah dengan menerbitkan Peraturan Pemerintah Nomor 19 Tahun 2005 tentang Standar Nasional Pendidikan (SNP) yang menjadi acuan minimal kualitas pendidikan, yaitu standar isi, standar proses, standar sarana prasarana, standar kompetensi lulusan, standar pengelolaan, standar pembiayaan, standar pendidik dan tenaga pendidik, dan standar penilaian. Madrasah yang bermutu karenanya adalah madrasah yang secara konsisten berorientasi pada implementasi SNP sebagaimana ditetapkan oleh pemerintah. Dengan kata lain, pemenuhan SNP tersebut akan menjadi menjadi tool untuk mempercepat meningkatkanya kualitas pendidikan di Indonesia. Sekolah/madrasah berkualitas akan menghasilkan lulusan (output) yang memiliki daya saing tinggi, mampu berkompetensi di dunia global, yang pada akhirnya akan menjadi salah satu satu tolok ukur kemajuan suatu bangsa.

\section{Analisis SWOT Pengembangan Madrasah Unggul}

Analisis terhadap lingkungan strategis baik internal maupun eksternal diperlukan guna mengetahui sasaran prioritas apa yang direncanakan di dalam menanggulangi masalah pendidikan dan mengembangkan mutu pendidikan madrasah. Untuk itu diperlukan analisis SWOT (Strength, Weakness, Opportunity and Threat) tentang kondisi pendidikan madrasah, yang sebenarnya tidak bisa lepas dari kondisi umum pendidikan di Indonesia. Asumsi penyusunan analisis SWOT ini adalah bahwa pendidikan madrasah merupakan bagian yang inheren dan tidak terpisahkan dari pendidikan nasional.

Berdasarkan asumsi tersebut, faktor pendukung keberhasilan pencapaian rencana strategis yang pada hakikatnya merupakan kekuatan (Strength) dalam pendidikan madrasah dapat diidentifikasi antara lain: 
1. Pengakuan atas hak dasar untuk memperoleh pendidikan telah dijamin di dalam Pembukaan Undang-Undang Dasar 1945 yang bertujuan untuk mencerdaskan kehidupan bangsa dan memajukan kesejahteraan umum;

2. Adanya aspek legal yang menjamin pengelolaan pendidikan menuju pendidikan yang bermutu dan memberdayakan seperti adanya Undang-undang Nomor 20 Tahun 2003 tentang Sistem Pendidikan Nasional dan Undangundang Nomor 14 Tahun 2005 tentang Guru dan Dosen;

3. Komitmen pemerintah untuk merealisasikan keputusan Mahkamah Konstitusi Nomor 13/PUU-VI/2008 tentang kewajiban pemerintah untuk mengalokasikan $20 \%$ dari APBN untuk pendanaan pendidikan, merupakan peluang untuk secara lebih leluasa merencanakan dan mengelola pendidikan madrasah yang berorientasi mutu;

4. Adanya reformasi dan regulasi yang pro pembangunan pendidikan seperti ketentuan Standar Pelayanan Minimal, Standar Nasional Pendidikan bahkan acuan internasional dalam meningkatkan mutu pendidikan;

5. SDM pengelola pendidikan madrasah yang sinergi membangun kinerja yang berkualitas;

6. Kebanggaan seluruh warga masyarakat dan rasa memiliki madrasah;

7. Koordinasi dan pemanfaatan terpadu sumber daya;

8. Kerja sama yang saling mendukung;

9. Sarana dan prasarana yang memadai untuk mendukung program aksi;

10. Kekayaan dan keragaman tradisi, seni dan budaya merupakan dasar untuk membentuk dan membangun watak, karakter dan budi pekerti luhur.

Selain kekuatan, kita juga melihat kelemahan yang harus diantisipasi dan dicarikan solusinya. Kelemahan tersebut antara lain adalah:

1. Sebagai imbas kualitas pendidikan nasional yang mutunya masih di bawah pencapaian mutu sejumlah negara pendiri ASEAN, yakni Singapura, Malaysia, Thailand dan Filipina maka masih diperlukan upaya yang besar demi meningkatkan mutu pendidikan madrasah;

2. Masih adanya anggapan masyarakat di sebagian wilayah tentang kurang pentingnya pendidikan formal, sehingga mereka cukup mendidik anaknya di pendidikan informal, yang berakibat menyulitkan pemberantasan buta aksara;

3. Lembaga pendidikan dinilai belum sepenuhnya mampu melahirkan lulusan yang bermutu dan berketerampilan dengan kompetensi keahlian yang cukup bagi menghadapi kehidupan yang penuh tantangan;

4. Sebagian besar pendidik, terutama guru PAUD dan MI banyak yang belum memenuhi kualifikasi akademik S1 atau D4 seperti persyaratan Undangundang Nomor 14 Tahun 2005 tentang Guru dan Dosen, kecuali itu juga adanya fakta bahwa persebaran tenaga pendidik tidak merata, dan umumnya bertumpu di wilayah perkotaan;

5. Banyak madrasah, terutama di wilayah pedesaan dan madrasah swasta tertentu yang belum memenuhi fasilitas pembelajaran seperti laboratorium, perpustakaan dan lain-lain, guna memenuhi ketentuan Standar Nasional Pendidikan;

6. Kurangnya aksesabilitas buku pelajaran terutama di wilayah pedesaan; 
7. Belum optimalnya penggunaan teknologi informasi dan masih banyak madrasah yang gagap dan asing dalam penggunaan e-learning, dengan disparitas yang amat mencolok antara wilayah perkotaan dan wilayah pedesaan;

8. Layanan pendidikan nonformal belum sepenuhnya mampu membekali warga belajar dengan berbagai jenis keterampilan yang dibutuhkan oleh pasar kerja;

9. Masih belum fokusnya kurikulum pendidikan madrasah, masih terus dicari implementasi yang efektif dan efisien dari proporsi $70 \%: 30 \%$ pendidikan umum dan pendidikan agama.

10. Diarasakan sampai saat ini pengembangan madrasah masih bersifat tambal sulam dan belum menemukan fokus dan arah yang tepat.

11. Proses pendidikan madrasah masih belum sesuai dengan visi dan misi pendidikan madrasah sendiri, masih bersifat parsial dan belum menyentuh keseluruhan yang integratif.

12. Belum adanya cetak biru pengembangan madrasah.

Selain kekuatan dan kelemahan, dalam globalisasi ini juga ada beberapa peluang (opportunity) sebagai berikut:

1. Sistem perdagangan dunia yang terbuka memberikan peluang dalam meningkatkan mutu pendidikan pada seluruh tataran pendidikan;

2. Pendidikan mutlak diperlukan guna menopang pengembangan ekonomi berbasis pengetahuan (education for the knowledge based economy);

3. Pembangunan pendidikan saat ini semakin disadari merupakan bagian penting dari upaya menyeluruh dan sungguh-sungguh dalam meningkatkan harkat dan martabat bangsa;

4. Peningkatan Indeks Pembangunan Manusia Indonesia disadari amat ditentukan oleh kualitas dan akses pendidikan, sehingga upaya untuk melaksanakan pemberantasan buta aksara dan angka partisipasi sekolah disadari merupakan upaya pokok dalam mencapai IPM yang tinggi;

5. Laju perkembangan IPTEKS dunia semakin cepat, untuk mengejar ketertinggalan dalam penguasaan IPTEKS hanya perbaikan mutu pendidikan yang terus menerus berkesinambungan dan pengembangan budaya riset di seluruh jenjang madrasah mulai dari jenjang pendidikan dasar sampai perguruan tinggi merupakan jawabannya;

6. Peluang yang dimiliki oleh pendidik dan tenaga kependidikan saat ini cukup prospektif. Dengan adanya Direktorat Tenaga Kependidikan, kegiatan yang berkaitan dengan usaha peningkatan mutu tenaga kependidikan akan dapat difasilitasi dengan baik. Semakin luasnya akses informasi melalui teknologi komunikasi dan informasi (ICT, Web dan sejenisnya) membuka peluang bagi pendidik dan tenaga kependidikan untuk belajar terus menerus meningkatkan kemampuan diri.

7. Munculnya arus yang kuat dari warga belajar dan stakeholders madrasah untuk memiliki cetak biru pengembangan madrasah berupa Rencana Induk Pengembangan (RIP) Pendidikan Madrasah, sebagai pedoman dan panduan pengembangan madrasah di Indonesia ke depan.

Meskipun demikian dalam memanfaatkan peluang yang ada, juga dihadapkan pada berbagai tantangan atau kendala (threat) yang diperkirakan akan dihadapi antara lain adalah: 
1. Adanya komitmen global yang mengikat untuk memperluas akses dan meningkatkan mutu pendidikan, dalam kerangka aksi Dakkar mengenai Pendidikan untuk Semua (PUS, Education for All).

2. Penerapan pengarusutamaan gender (PUG, gender mainstream) di Indonesia menghadapi kendala karena pada sebagian masyarakat masih menganggap tidak ada perlunya bagi perempuan bersekolah tinggi-tinggi.

3. Masih adanya keengganan sejumlah satuan pendidikan yang dikelola Yayasan untuk menerapkan Manajemen Berbasis Madrasah/Sekolah, karena dianggap mencampuri urusan Yayasan dalam mengelola pendidikan. Sementara itu bahkan di sejumlah madrasah negeri terutama di wilayah pedesaan masih dijumpai kegagapan dalam menerapkan Manajemen Berbasis Sekolah/Madrasah (MBS);

4. Tantangan yang dihadapi pendidik dan tenaga kependidikan dalam waktu dekat ini adalah merespon kesungguhan pemerintah untuk meningkatkan mutu pendidik dan tenaga kependidikan. Menampilkan kinerja optimal untuk bersaing dengan pendidik dan tenaga kependidikan dari negara lain yang saat ini sudah boleh bekerja di negeri ini sebagai konsekuensi dari era WTO;

5. Tantangan jangka pendek yang dihadapi adalah segera menyiapkan diri, mengubah pola pikir untuk sanggup berkompetisi secara terbuka, selalu mencari informasi baru dan memperbaharui diri, baik pengetahuan, keterampilan dan sikap kerja. Pada jangka menengah pendidik dan tenaga kependidikan harus mampu menjadi manusia pembelajar yang selalu meningkatkan dirinya sesuai dengan tantangan perubahan. Pada jangka panjang tantangan pendidik dan tenaga kependidikan adalah kemampuan menampilkan citra diri sebagai individu yang sadar terhadap produktivitas kerja, prestasi kerja, dan perilaku yang adaptif dalam pengembangan diri untuk menyesuaikan kemampuannya sesuai tuntutan profesionalnya.

\section{Upaya dan Strategi Pengembangan Madrasah Unggul}

Syarat menuju pengembangan madrasah unggulan antara lain ketersediaan tenaga pendidikan yang profesional, kelengkapan sarana dan prasarana, perlu ditangani dengan sistem manajemen profesional yang modern, transparan dan demokratis, dan adanya kurikulum yang sesuai dengan kebutuhan masyarakat dan tantangan dunia modern (Burhanudin dan Afrianty, 2006, p. 42). Selain itu, madrasah juga perlu memberikan perhatian untuk senantiasa meningkatkan kualitas, mengembangkan inovasi dan kreativitas, membangun jaringan kerjasama (networking), dan memahami karakteristik pelaksanaan otonomi daerah.

Pada akhirnya, keunggulan sebuah madrasah akan sangat ditentukan oleh keberhasilan peserta didik (output dan outcome) yang memiliki prestasi yang membanggakan. Dalam konteks keberhasilan madrasah, maka keberhasilan tersebut tidak saja diukur dari nilai akademik yang tinggi, tetapi juga harus dilihat dari perilaku yang Islami (akhlaqul karimah).

Madrasah unggulan dimaksudkan sebagai center for excellence. Madrasah Unggulan diproyeksikan sebagai wadah menampung putra-putri terbaik masing-masing daerah untuk dididik secara maksimal tanpa harus pergi ke daerah lain. Dengan demikian terjadinya eksodus SDM terbaik suatu daerah ke daerah lain dapat diperkecil, dan sekaligus menumbuhkan persaingan sehat antara daerah dalam menyiapkan SDM mereka. 
Karena menjadi center for excellence anak-anak terbaik, maka kesempatan belajar di kedua jenis madrasah ini haruslah melalui proses seleksi yang ketat dan dengan berbagai kententuan lainnya. Madrasah ini diperkuat oleh keberadaan majelis madrasah yang juga memiliki peran penting dalam pengembangannya.

Madrasah unggul dikembangkan untuk mencapai keistimewaan dalam keluaran pendidikannya. Untuk mencapai keistimewaan tersebut, maka masukan, proses pendidikan, guru dan tenaga kependidikan, manajemen, layanan pendidikan, serta sarana penunjangnya harus diarahkan untuk menunjang tercapainya tujuan tersebut.

Dengan memerhatikan fakta-fakta yang ada, maka ciri-ciri madrasah unggul yang dapat diidentifikasi ialah (1) prestasi akademik dan nonakademik di atas rata-rata sekolah yang ada di daerahnya; (2) sarana dan prasarana dan layanan yang lebih lengkap; (3) sistem pembelajaran lebih baik dan waktu belajar lebih panjang; (4) melakukan seleksi yang cukup ketat terhadap pendaftar; (5) mendapat animo yang besar dari masyarakat, yang dibuktikan banyaknya jumlah pendaftar dibanding dengan kepasitas kelas; (6) biaya sekolah lebih tinggi dari sekolah di sekitarnya.

Kementerian Agama sebagai salah satu pelaksana program pendidikan sekolah telah mengembangkan beberapa jenis madrasah unggulan, yaitu: Madrasah Aliyah Keagamaan, Madrasah Tsanawiyah Terbuka, Madrasah Model, Madrasah Aliyah Unggulan dan Madrasah Aliyah Keterampilan. Pengembangan kelembagaan di lingkungan madrasah dan sekolah Islam tidak hanya berhenti pada beberapa jenis sekolah di atas, tetapi terus berkembang hingga saat ini. Wacana pengembangan sekolah terpadu dan bertaraf internasional yang saat ini banyak diminati merupkan bagian dari pengembangan lebih lanjut dari beberapa jenis lembaga pendidikan di atas.

Oleh karena itu, strategi pengembangan madrasah perlu dirancang agar mampu menjangkau jangka panjang, dan mampu menghasilkan perubahan yang signifikan, ke arah pencapaian visi dan misi lembaga, sehingga akan memiliki keunggulan komparatif dan kompetitif baik di tingkat lokal, regional, nasional bahkan internasional. Dengan demikian pengembangan madrasah tidak boleh apriori terhadap trend pendidikan yang dibawa oleh proses globalisasi, internasionalisasi dan universalisasi, misalnya komputerisasi, vokasionalisasi dan ekonomisasi. Namun di pihak lain pengembangan madrasah harus tetap tegar dengan karakteristik khas yang dimilikinya sebagai perisai dan benteng pertahanan masyarakat dari persoalan-persoalan dekadensi moral dan melemahnya nilai-nilai spiritual.

Strategi pengembangan madrasah harus mengacu kepada strategi pengembangan pendidikan nasional dan diwujudkan dalam lima strategi pokok, yakni; (1) perluasan dan pemerataan memperoleh kesempatan pendidikan di madrasah; (2) peningkatan layanan pendidikan di madrasah; (3) peningkatan mutu dan relevansi pendidikan madrasah; (4) pengembangan sistem dan manajemen pendidikan yang akuntabel, dan (5) pemberdayaan kelembagaan untuk meningkatkan pencitraan madrasah.

Sebenarnya kelima strategi pokok tersebut tetap berfokus kepada tiga pilar pembangunan pendidikan nasional. Strategi peningkatan layanan pendidikan di madrasah dan strategi pemberdayaan kelembagaan untuk meningkatkan pencitraan madrasah bermuara kepada pilar tata kelola akuntabilitas dan pencitraan publik (pilra ketiga dalam pembangunan pendidikan nasional).

Strategi perluasan dan pemerataan kesempatan pendidikan di madrasah difokuskan kepada pelaksanaan wajib belajar 9 tahun, bahkan di perkotaan sudah berkembang pada wajib belajar 12 tahun. Indikator kunci keberhasilan strategi ini antara lain adalah; (1) mayoritas penduduk berpendidikan minimal MTs diwujudkan oleh meningkatnya APK 
pada semua jenjang dan jenis madrasah, (2) meningkatnya budaya belajar yang ditunjukkan dengan meningkatnya angka melek aksara; dan (3) proporsi jumlah penduduk yang kurang beruntung yang mendapat kesempatan pendidikan semakin meningkat.

Strategi peningkatan layanan pendidikan di madrasah difokuskan pada upaya mencegah peserta didik agar tidak putus sekolah dan mempertahankan mutu pendidikan agar tidak semakin menurun. Indikator kunci keberhasilan implementasi stretegi ini adalah; (1) memperkecil angka putus sekolah di madrasah; (2) meningkatnya APK dan APM, baik MI dan MTs terutama bagi peserta didik yang kurang beruntung (miskin, tinggal di wilayah terpencil, broken home dan sebagainya); (3) mendorong kembali dan memfasilitasi siswa yang telanjur putus sekolah; (4) mempertahankan dan meningkatkan mutu proses kegiatan belajar dan mengajar di madrasah, termasuk penggunaan ICT dalam pembelajaran, meskipun dana yang terbatas.

Strategi peningkatan mutu dan relevansi pendidikan di madrasah difokuskan kepada pengembangan empat aspek yakni kurikulum, guru dan tenaga kependidikan lain, sarana pendidikan dan kepemimpinan madrasah. Dalam kaitan ini dilaksanakan pengembangan kurikulum berkelanjutan di semua jenjang dan jenis madrasah, dilakukan pembinaan profesi guru madrasah, dilaksanakan peningkatan pengadaan dan pendayagunaan sarana dan prasarana pendidikan di madrasah serta pengembangan kepemimpinan di madrasah yang berlandaskan prinsip manajemen berbasis madrasah.

Strategi pengembangan manajemen pendidikan madrasah berkenaan dengan upaya pengembangkan sistem manajemen madrasah sehingga secara kelembagaan madrasah memiliki kemampuan: (1) mengembangkan prakarsa dan kemampuan kreatif dalam mengelola pendidikan, (2) mengembangkan organisasi pendidikan madrasah yang lebih berorientasi profesionalisme, dan (3) layanan pendidikan yang semakin cepat, terbuka, adil, dan merata.

Strategi pemberdayaan kelembagaan madrasah ditekankan kepada pemberdayaan madrasah sebagai pusat pembelajaran, pendidikan dan pembudayaan. Indikator kunci keberhasilannya antara lain adalah: (1) tersedianya madrasah yang semakin bervariasi dengan dukungan organisasi yang efektif dan efisien; (2) mutu dan sarana dan prasarana madrasah yang semakin meningkat dan iklim pembelajaran yang semakin kondusif bagi peserta didik, dan (3) tingkat kemandirian madrasah yang semakin tinggi.

\section{Unsur Pendukung Pengembangan Madrasah Unggul}

Dalam pelaksanaannya, pengembangan madrasah unggul perlu mendapat dukungan beberapa unsur pokok yang harus terpenuhi. Idealnya kata unggulan itu memiliki performansi yang sebanding lurus dengan amanah yang diembannya guna memenuhi harapan dan kepercayaan dari stakeholders, orangtua siswa, masyarakat dan pemerintah.

Menurut Arifin (2008, pp. 322-323), unsur pendukung madrasah atau sekolah Islam berprestasi (unggul) itu setidaknya ada sembilan faktor, yaitu:

1. Faktor sarana dan prasarana. Meliputi (a) fasilitas sekolah yang lengkap dan memadai, (b) sumber belajar yang memadai dan (c) sarana penunjang belajar yang memadai.

2. Faktor guru. Meliputi (a) tenaga guru mempunyai kualifikasi memadai, (b) kesejahteraan guru terpenuhi, (c) rasio guru-murid ideal, (d) loyalitas dan komitmen tinggi, dan (e) motivasi dan semangat kerja guru tinggi.

3. Faktor murid. Meliputi (a) pembelajaran yang terdiferensiasi, (b) kegiatan intra dan ekstrakulikuler bervariasi, (c) motivasi dan semangat belajar tinggi, (d) pemberdayaan belajar bermakna. 
4. Faktor tatanan organisasi dan mekanisme kerja. Meliputi (a) tatanan organisasi yang rasional dan relevan, (b) program organisasi yang rasional dan relevan, (c) mekanisme kerja yang jelas dan terorganisasi secara tepat.

5. Faktor kemitraan. Meliputi (a) kepercayaan dan harapan orangtua tinggi, (b) dukungan dan peran serta masyarakat tinggi, (c) dukungan dan bantuan pemerintah tinggi.

6. Faktor komitmen/sistem nilai. Meliputi (a) budaya lokal yang saling mendukung, (b) nilai-nilai agama yang memicu timbulnya dukungan positif.

7. Faktor motivasi, iklim kerja, dan semangat kerja. Meliputi (a) motivasi berprestasi pada semua komunitas sekolah, (b) suasana, iklim kerja dan iklim belajar sehat dan positif, dan (c) semangat kerja dan berprestasi tinggi.

8. Faktor keterlibatan Wakil Kepala sekolah dan guru-guru. Meliputi (a) keterwakilan kepala sekolah dalam pembuatan kebijakan dan pengimplementasiannya, (b) keterwakilan kepala sekolah dan guru-guru dalam menyusun kurikulum dan program-program sekolah, dan (c) keterlibatan wakil kepala sekolah dan guru-guru dalam perbaikan dan inovasi pembelajaran.

9. Faktor kepemimpinan kepala sekolah. Meliputi (a) piawai memanfaatkan nilai religio-kultural, (b) piawai mengkomunikasikan visi, inisiatif, dan kreativitas, (c) piawai menimbulkan motivasi dan membangkitkan semangat, piawai memperbaiki pembelajaran yang terdiferensiasi, (e) piawai menjadi pelopor dan teladan, dan (f) paiwai mengelola administrasi sekolah.

Dalam rangka mewujudkan pengembangan madrasah dan sekolah Islam unggulan memerlukan langkah dan upaya yang fisibel dan kredibel (Mujtahid, 2011, p. 286). Oleh karena itu, madrasah dan sekolah Islam unggulan harus bersaing dengan beberapa lembaga pendidikan yang sedang mencanangkan program rintisan madrasah bertaraf internasional (RMBI) atau rintisan sekolah bertaraf internasional (RSBI). Perencanaan (pengembangan) membutuhkan langkah strategis untuk mengembangkan keunggulan madrasah dan sekolah Islam unggulan. Penguatan keunggulan lembaga tersebut melalui cara membangun cita dan kultur akademik yang kokoh. Cita-cita didirikannya madrasah dan sekolah Islam adalah sangat mulia, yaitu ingin melahirkan lulusan yang unggul di bidang akademik, spiritual dan moral. Selama ini, hanya ada dua lembaga pendidikan yang melahirkan identitas ilmuwan yang berbeda, yaitu pondok pesantren yang ingin melahirkan ulama (ahli agama) dan sekolah umum yang ingin melahirkan kaum intelektual (akademis). Madrasah dan sekolah Islam unggulan selama ini sesungguhnya bercita-cita ingin meraih kedua corak tersebut, yakni mencetak calon ulama sekaligus intelek atau intelek yang sekaligus ulama. Visi dan misi yang ideal tersebut harus diperjuangkan dan diwujudkan melalui pembenahan berbagai aspek, baik terkait dengan konsep bangunan keilmuannya (kurikulum), sumber daya manusia, pengembangan sarana dan prasarana, kelembagaan maupun leadership dan managerialnya (Mujtahid, 2011, p. 286).

Gambar di bawah ini akan menjelaskan skema pengembangan madrasah unggul dan menjadi rujukan layanan pendidikan bagi masyarakat. 


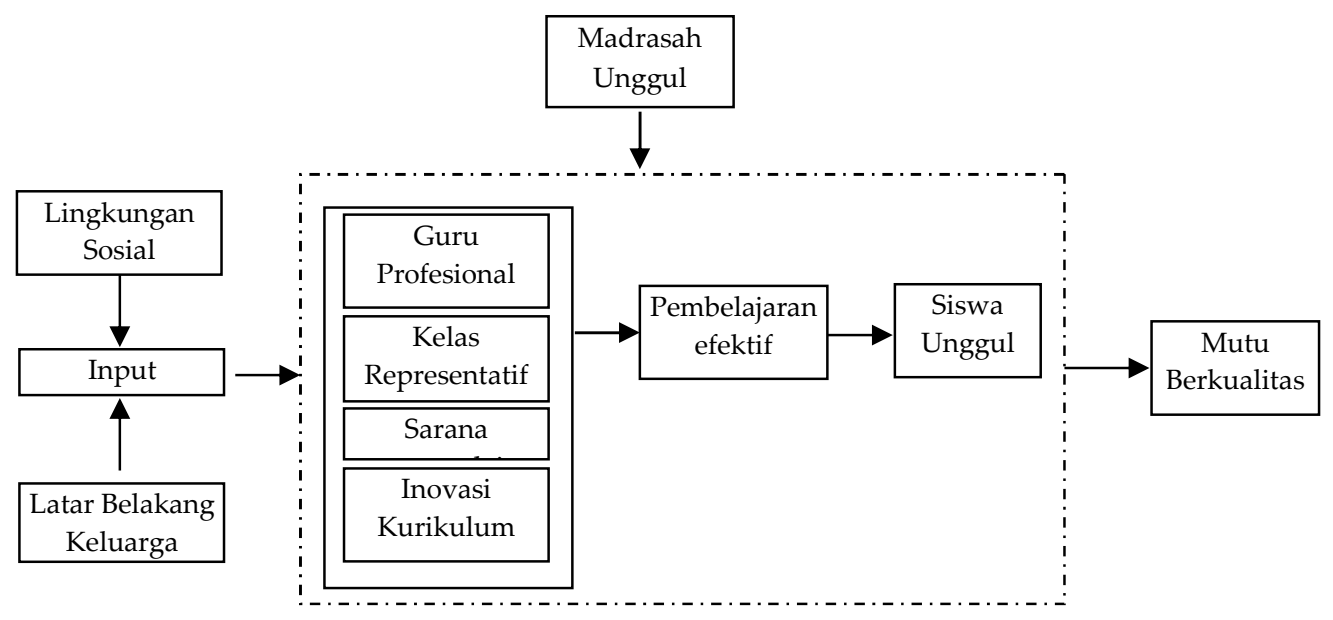

Gambar 1: Skema Pengembangan Madrasah Unggul. Adaptasi Bafadhal (2003) dan Depag RI (2004)

Dilihat dari gambar di atas, dapat dijelaskan bahwa adanya madrasah unggul perlu ditunjang dengan berbagai aspek di antaranya adanya input yang unggul, guru yang profesional, sarana yang memadai, kurikulum yang inovatif, ruang kelas atau pembelajaran yang representatif, sehingga dapat mendorong terciptanya pembelajaran yang efektif dan efisien akhirnya dapat menghasilkan out put yang unggul dan berkualitas. Hal senada diungkapkan oleh Bafadhal (2003, p. 28) dan Depag RI (2004, pp. 1-5) bahwasannya untuk mencapai madrasah yang unggul dituntut adanya tenaga, fasilitas, dan dana yang memadai, dan tidak semua sekolah/madrasah dapat memenuhinya, serta secara teknis, pengembangan madrasah unggulan menuntut adanya tenaga yang profesional dan fasilitas yang memadai.

Berdasarkan uraian di atas dapat dikemukakan bahwa langkah strategis yang perlu dilakukan untuk mengembangkan madrasah unggul dan menjadi rujukan layanan pendidikan bagi masyarakat antara lain:

1. Membangun Pola Pikir Kolektif. Untuk mengembangkan mutu madrasah unggulan membutuhkan pandangan, cita-cita, imajinasi, nilai-nilai keyakinan yang kuat dan kolektif. Aspek kepentingan institusi harus dibangun secara kolektif dengan orientasi yang sama. Kepentingan institusi harus dikedepankan daripada kepentingan individu. Sedangkan, pola pikir (mindset) yang perlu dibangun pada lembaga pendidikan madrasah unggulan adalah menanamkan keyakinan dan tekad bersama kepada seluruh warga sekolah atau madrasah. Seluruh komponen madrasah haris digerakkan untuk memperjuangkan keunggulan institusi, dengan cara mengimplementasikan visi, misi, tradisi, dan orientasi madrasah. Mindset secara kolektif tersebut menjadi modal sosial (social capital) bagi pengembangan kultur akademik di madrasah unggulan ke depan. Madrasah unggulan membutuhkan lingkungan akademik yang handal dan tekad bersama. Inspirasi dan semangat inilah yang harus dibangun dan dikembangkan untuk meningkatkan mutu akademik dan institusi madrasah.

2. Menciptakan Inovasi secara Terus Menerus. Keunggulan lembaga madrasah sesungguhnya terletak pada inovasinya. Inovasi merupakan usaha dan kerja nyata untuk mencari dan membuat hal baru demi meraih kemajuan dan keunggulan bagi lembaga pendidikan madrasah secara berkelanjutan. Inovasi harus didasarkan pada kebutuhan agar lembaga madrasah dan se- 
kolah Islam itu terus maju dan berkembang. Inovasi secara terus-menerus harus digerakkan untuk memacu kualitas dan daya saing yang tinggi. Inovasi tidak saja diperlukan untuk selalu menyempurnakan kondisi madrasah, tetapi juga penting untuk membangun keutuhan (holistika) tujuan pendidikan madrasah dan sekolah Islam. Usaha dan kerja nyata itu ditempuh secara serentak, menyeluruh dan integratif di antara beberapa elemen yang ada di madrasah. Bentuk inovasi itu misalnya, perbaikan atau penambahan sarana fisik, akademik, tenaga guru dan karyawan, perekrutan siswa dan seluruh aspek yang ada. Inovasi lainnya misalnya menciptakan kultur madrasah berbasis bilingual, mentradisikan hafalan Alquran, menggerakkan pusat seni dan olah raga, dan seterusnya. Modal seperti inilah yang harus dituangkan dalam visi dan orientasi madrasah unggul itu. Dengan cara seperti itulah madrasah unggulan dapat menawarkan sesuatu yang baru, yang khas dan memiliki keunikan yang diperhitungkan oleh masyarakat. Tugas ini membutuhkan seorang pemimpin yang efektif dan didukung oleh warga madrasah yang dedikatif dan dapat bekerja secara extra role.

3. Memanfaatkan Teknologi Informasi. Untuk memajukan madrasah dan sekolah Islam yang merata dan berkualitas membutuhkan energi pikiran, tenaga dan usaha yang konsisten dan berkelenjutan. Sudah saatnya madrasah mengembangkan pembelajaran berbasis digital, selain yang sudah ada, guna mengefektifkan program dan kegiatan pendidikan yang lebih maksimal. Pendidikan madrasah tidak boleh tertinggal di bidang teknologi informasinya. Dengan pemanfaatan teknologi informasi tersebut para siswa dapat belajar lebih intensif, di samping melalui sistem reguler dan kurikuler. Teknologi informasi perlu dimanfaatkan sebagai sumber belajar yang mudah dan berjangkauan luas, tanpa hambatan waktu dan tempat. Untuk menciptakan mutu layanan akademik, menurut hemat penulis dapat dikembangkan sistem digital di madrasah. Hampir semua aktivitas akademik melibatkan internet, sehingga program-program madrasah dapat berjalan secara sinergis antara unit satu dengan unit-unit lainnya. Melalui program digitalisasi ini, upaya untuk memajukan madrasah sangatlah mudah diukur dan dirasakan oleh para pengguna.

4. Membangun Kepemimpinan yang Terbuka dan Berprinsip. Dalam rangka pengembangan madrasah unggul dibutuhkan sistem manajemen yang terbuka (open management) termasuk di antaranya adalah perilaku kepemimpinan. Diperlukan kepemimpinan yang efektif: kepemimpinan yang lebih interaktif dan visioner-yang konsisten memobilisasi cita-cita, nilainilai, dan transformasi gagasan dan institusi-; kepemimpinan yang dijalankan tidak berdasarkan naluri, intuisi, dan nalar subjektif, tetapi yang dijalankan berdasarkan logika dan akal pikiran yang sehat, serta dibangun di atas kerangka objektivitas-akademik yang tinggi; dan kepemimpinan yang dijalankan haruslah dapat merefleksikan tumbuhnya suasana akademik yang sehat, komunikasi, koordinasi, dan interaksi yang efektif serta mengimplementasikan praktik-praktik baik (good practices) yang berkembang secara dinamis dalam institusi.

5. Meningatkan Kualitas Tata Kelola Madrasah. Madrasah yang unggul adalah madrasah yang secara terus-menerus mempebaiki sisitem dan tata kelola organisasinya. Langkah awalnya ialah penataan struktur organisasi, 
melakukan analisis jabatan secara tepat, membuat uraian tugas, menyusun instruksi kerja, dan membuat standar operasional prosedur (SOP). Melalui langkah ini, maka diharapkan semua komponen dapat bekerja secara efektif sehingga dapat memberikan layanan pendidikan yang maksimal.

6. Meningatkan Kualitas Sistem Rekruitmen Siswa Baru. Siswa adalah komponen input madrasah. Untuk mendapatkan output yang baik, diperlukan sistem rekruitmen yang baik dan berkulitas. Permasalahan yang ada selama ini ialah sistem rekruitmen siswa baru kurang konsisten menerapkan prosedur yang telah ditetapkan. Untuk mengembangkan madrasah yang unggul, dibutuhkan proses seleksi atau pola rekruitmen yang standar sebagaimana telah diterapkan di beberapa madrasah atau sekolah unggulan.

7. Meningatkan Kuantititas dan Kualitas Kegiatan Ekstrakurikuler. Pengembangan minat dan bakat siswa perlu mendapat perhatian. Proses pembelajaran di madrasah tidak hanya berpusat pada pemenuhan kompetensi kognitif melalui pembelajaran di kelas, tetapi juga kegiatan di luar kelas yang bersifat ekstrakurikuler untuk pemenuhan kompetensi atau keterampilan hidup (life sklills). Program-program pengembangan minat dan bakat siswa harus juga menjadi perhatian.

8. Meningkatkan Kegiatan Pembinaan dan Pengembangan Profesi Keguruan. Orientasi pembinaan dan pengembangan profesi keguruan harus bertumpu pada tiga kegiatan utama yaitu pengembangan diri, publikasi ilmiah, dan karya inovatif. Pengembangan diri dapat dilakukan melalui kegiatan pendidikan dan pelatihan, seminar, dan workshop tentang praktik pendidikan dan pembelajaran. Publikasi ilmiah dapat dilakukan dengan mendorong dan memfasilitasi para guru melakukan penelitian baik berupa penelitian tindakan kelas maupun penelitian eksperimen. Hasil-hasil penelitian itu dapat difasilitasi untuk dipublikasi melalui jurnal-jurnal ilmiah. Oleh karena itu, program-program literasi bagi guru perlu ditingkatkan. Demikian pula, karya inovatif guru perlu didorong terutama karya-karya inovatif dalam bidang pembelajaran.

\section{Kesimpulan}

Kunci untuk membangun madrasah unggulan harus memenuhi beberapa kriteria, yaitu ketersediaan tenaga pendidikan yang profesional, kelengkapan sarana dan prasarana, sistem manajemen profesional yang modern, transparan dan demokratis, dan adanya kurikulum yang sesuai dengan kebutuhan masyarakat dan tantangan dunia modern. Selain itu, madrasah juga perlu memberikan perhatian untuk senantiasa meningkatkan kualitas, mengembangkan inovasi dan kreativitas, dan membangun jaringan kerjasama (networking), sehingga input dan output menjadi baik.

Dengan kata lain, untuk mengembangkan madrasah unggulan memerlukan daya dukung yang efektif dan fungsional, seperti sumber daya manusia yang unggul, saranaprasarana (ruang belajar yang representatif, perpustakaan dan laboratorium), fasilitas penunjang (boarding/ma'had, masjid atau mushala). Madrasah unggulan harus dirancang sesuai dengan visi-misi dan tujuan kelembagaan, analisis kebutuhan sistem akademik dan kelembagaan, dan memahami konteks geografis dan budaya. Sedangkan, pengembangannya memerlukan kebersamaan dan maindset secara kolektif, inovasi secara terus menerus, dan memanfaatkan teknologi informasi, membangun kepemimpinan yang terbuka dan berprinsip, meningatkan kualitas tata kelola madrasah, me- 
ningatkan kualitas sistem rekruitmen siswa baru, meningatkan kuantititas dan kualitas kegiatan ekstrakurikuler, dan meningkatkan kegiatan pembinaan dan pengembangan profesi keguruan.

\section{Daftar Pustaka}

Arifin, I. (2008). Kepemimpinan Kepala Sekolah dalam Mengelola Sekolah Berprestasi. Yogyakarta: Aditya Media.

Bafadal, I. (2003). Manajemen Peningkatan Mutu Sekolah Dasar: dari Sentralisai Menuju Desentralisasi. Jakarta: Bumi Aksara.

Burhanudin, Jajat dan Afrianty, D. (ed. . (2006). Mencetak Muslim Modern, Peta Pendidikan Islam Indonesia. Jakarta: PT Danim.

Depag RI. (2004). Desain Pengembangan Madrasah. Jakarta: Direktorat Jenderal Kelembagaan Agama Islam.

Djojonegoro, W. (1998). Sekolah Unggulan. SINERGI, Jurnal Populer Sumber Daya Manusia, Volume 1, 15.

Fachruddin, F. (1998). Madrasah Model: Indikator Obyektif dan Operasionalnya. Jurnal Madrasah, PPIM IAIN Syarif Hidayatullah, Vol. 3, Nomor 3.

Jalal, F. (2012). Strategi dan Arah Pengembangan Sekolah Unggul.

Mastuhu. (1994). Pemberdayaan Sistem Pendidikan Islam. Jakarta: INIS.

Moedjiarto. (2002). Sekolah Unggul. Surabaya: Duta Graha Pustaka.

Muhaimin. (2005). Pengembangan Kurikkulum Pendidikan Agama Islam di Sekolah, Madrasah dan Perguruan Tinggi. Jakarta: Raja Grafindo Persada.

Mujtahid. (2011). Pengembangan Madrasah dan Sekolah Islam Unggulan. Jurnal El-Hikmah, Vol. IX, Nomor 1.

Nata, A. (2002). Tafsir Ayat-Ayat Pendidikan. Jakarta: Raja Grafindo Persada.

Subhan, F. (2006). Membangun Sekolah Unggulan dalam Sistem Pesantren. Surabaya: Alpha.

Zayadi, A. (2005). Desain Pengembangan Madrasah. Jakarta: Dirjen Kelembagaan Pendidikan Islam Depag RI.[] 